\title{
PHORETIC RELATIONSHIP BETWEEN LUSTROCHERNES GROSSUS (PSEUDOSCORPIONIDA: CHERNETIDAE) AND ODONTOTAENIUS STRIATOPUNCTATUS (COLEOPTERA: PASSALIDAE)
}

\author{
María Luisa CASTILLO ${ }^{1}$ \& Gabriel A. VILLEGAS-GUZMÁN²
}

\author{
${ }^{1}$ Instituto de Ecología, A. C. Km 2.5 Antigua carretera a Coatepec \# 351, \\ Congregación El Haya, Xalapa, Veracruz, C. P. 91000, Apartado Postal 63, México Autor de correspondencia: \\ $<$ marilu.castillo@inecol.mx> \\ ${ }^{2}$ Laboratorio de Acarología, ENCB, Instituto Politécnico Nacional, Departamento de Zoología, Prolongación \\ Carpio y Plan de Ayala s/n, Col. Casco de Santo Tomás, C. P. 11340, México, D.F. <gabrvill@yahoo.com> \\ Recibido: 04/06/2015; aceptado: 05/01/2016
}

\begin{abstract}
Castillo, M. L. \& Villegas-Guzmán, G. A. 2016. Phoretic relationship between Lustrochernes grossus (Pseudoscorpionida: Chernetidae) and Odontotaenius striatopunctatus (Coleoptera: Passalidae). Acta Zoológica Mexicana (n.s.), 32(1): 71-80.
\end{abstract}

\begin{abstract}
Phoresy is considered a non-parasitic partnership between a small animal (phoront) and a large one (host) that result in phoront transportation by the host. Throughout two years of observation and nursing of 16 family groups of the passalid Odontotaenius striatopunctatus, we noticed the presence of the pseudoscorpion Lustrochernes grossus within 11 of their 16 nests, which consisted of rotten wood logs (30 cm long $\times 15-20 \mathrm{~cm}$ in diameter) cut into $2 \mathrm{~cm}$ segments and secured with rubber bands to facilitate observation. The presence of pseudoscorpions became evident from the moment the passalids started building their nests creating space and food for their young. Evidence was found that pseudoscorpions can go under the elytra of passalids. Their presence did not prevent the reproduction of the beetles, performed in 13 of the 16 set nests (Fischer's exact test: $P=$ $0.71, N=16$ ): neither was the number of passalids offspring modified (Mann Whitney $U=11.50, P=0.2553$ ). On three occasions during spring, L. grossus females carrying brood sac was documented. In this facultative relationship, phoresy and phagophilia could be involved; some hypotheses on the factors that may interfere with it are posed.

Key words: passive phoresy, phoretic-phagophilic relationship, subsocial insects, sinhospitality, saproxylic fauna.
\end{abstract}

\section{INTRODUCTION}

The passalid Odontotaenius striatopunctatus (Percheron, 1835 ) is among the saproxylophagous organisms widely distributed in Mesoamerica. It inhabits tropical and subtropical humid forests, as well as humid temperate forests, mountain cloud forest and areas of secondary vegetation, between sea level and 2100 m (Reyes-Castillo 1970). It preferentially colonizes logs in an intermediate state of decomposition, building galleries between the sapwood
Castillo, M. L. \& Villegas-Guzmán, G. A. 2016. Relación forética entre Lustrochernes grossus (Pseudoscorpionida: Chernetidae) y Odontotaenius striatopunctatus (Coleoptera: Passalidae). Acta Zoológica Mexicana (n.s.), 32(1): 71-80.

RESUMEN. La foresia es una relación no parasitica entre un animal grande (huésped) y un animal pequeño (foronte) cuyo objetivo es la transportación del foronte por el huésped. A través de dos años de observación y crianza de 16 grupos familiares del coleóptero Odontotaenius striatopunctatus, se pudo observar la presencia del pseudoescorpión Lustrochernes grossus en 11 de sus nidos, los cuales consistieron de trozas de madera podrida $(30 \mathrm{~cm}$ de largo $\times 15-20 \mathrm{~cm}$ de diámetro) cortada en rebanadas de $2 \mathrm{~cm}$ y sujetas con ligas para facilitar las observaciones. La presencia de los pseudoescorpiones se hizo evidente desde que los pasálidos inician la construcción de sus nidos creando espacio y alimento para sus crías. Se encontró evidencia que los pseudoescorpiones pueden llegar bajo los élitros de los pasálidos. Su presencia no impidió la reproducción de los coleópteros realizada en 13 de los 16 nidos (Fischer's exact test: $P=0.71, N=16$ ), ni se modificó el número de crías de los coleópteros (Mann Whitney: $U=11.50, P=0.2553)$. En tres ocasiones durante la primavera se documentó la presencia de hembras de L. grossus llevando su saco de crianza. En esta relación facultativa, foresia y fagofilia podrían estar involucradas; se plantean algunas hipótesis en relación a los factores que puedan interferir en ella.

Palabras clave: foresia pasiva, relaciones forético-fagofilícas, insectos subsociales, sinhospitalidad, fauna saproxílica.

and heartwood of dead trees, which then become a resource that is used as both habitat and food (Castillo \& Reyes-Castillo 2003).

Odontotaenius striatopunctatus shows a subsocial behavior characterized mainly by biparental breeding care, larval food preparation from a mixture of their excreta and chewed timber innoculated with microorganisms (external rumen). They also build a cocoon to protect the larva before metamorphosis; the cocoon can be repaired by the parents and siblings, in case of damage (Valenzuela \& 
Castillo 1983; Reyes-Castillo \& Halffter 1984; Schuster \& Schuster 1997).

Pseudoscorpions are frequently observed within passalid galleries and their presence has been documented since the late nineteenth century. Vachon (1940) quotes: Waterhouse 1878, Hagen1879 and Ihering 1893, who recorded a Chelifer sp. on Passalus sp. and Tullgren 1912, who lists different species of pseudoscorpions on the passalid Pelopides tridens Wiedemann, 1823. From his observations in Ecuador, Ohaus (1909) cites the presence of pseudoscorpions under the elytra of a passalid. Reyes-Castillo \& Hendrichs (1975), mentioned pseudoscorpions on passalids collected in night flying, attracted to light traps. Aguiar \& Bührnheim (1992, 1998 and 2011) documented the presence of various species of pseudoscorpions with numerous species of passalids in Brazilian Amazon forest. Villegas-Guzman \& Reyes-Castillo (2005, 2012) cite new records of pseudoscorpions on passalids in the Mexican states of Chiapas and Veracruz.

Encounters between Pseudoscorpiones and Coleoptera have shown interesting interactions, such as those between the cerambycid Acrocinus longimanus Linnaeus 1758 and the pseudoscorpion Cordylochernes scorpioides (Linnaeus, 1758) where an interesting phoretic relationship, as well as intense sexual selection occurs in both taxa, (Zeh et al. 1992; Zeh \& Zeh 1992a, 1992b, 1994, 1997).

Pseudoscorpions of the genus Lustrochernes Beier have been reported on various insects and even on vertebrates (Villegas-Guzmán \& Pérez 2005a): on Orthoptera: Acrididae (Hoff 1947), Coleoptera: Cerambycidae (Muchmore 1971a), Curculionidae (Beier 1948), Elateridae, (Beier 1948), Diptera: Calliphoridae (Beier 1948) and obviously on various species of Passalidae (Aguiar \& Bührnheim 1992, 1998, 2011) (Table 1).

Unlike the close relationship between A. longimanus and C. scorpioides, there is no evidence of any specific association pseudoscorpion-passalid; only Beier (1948) mentions a relation between the pseudoscorpion Dithella javana (Tullgren) and the passalid $P$. tridens. In most cases, pseudoscorpions found on passalids are not species-specific phoretics or can be found on members of other Coleoptera families and subfamilies, especially Staphylinidae, Cerambycidae, Elateridae and Platypodinae (Reyes-Castillo \& Hendrichs 1975; Aguiar \& Bührnheim 1998).

As for Lustrochernes grossus (Banks 1893), it has been recorded on the spider Olios fasciculatus (Hoff \& Jennings 1974), on cerambycids Ergates spiculatus (Muchmore 1971a) and Trogosoma chiricahuae (Muchmore 1991), as well as in rodent's nests (Villegas-Guzman \& Pérez 2005b; Francke \& Villegas-Guzman 2007). On Passalidae, it has been recorded with the species Heliscus tropicus (Percheron), Passalus interstitialis Eschscholtz and Passalus punctatostriatus Percheron (Villegas-Guzmán \& Reyes-Castillo 2005, 2012).

Authors such as Szymkowiak et al. (2007) and TizoPedroso \& Del-Claro (2007) consider that due to the small size of pseudoscorpions (2-12 mm), their long distance travelling is limited, which is why phoresy has proven to be an effective mechanism for transport and colonization of new habitats. Phoresy is considered a non-parasitic partnership between a small animal (phoront) and a large one (host), which results in phoront transportation (Muchmore 1971a). Poinar et al. (1998) and Tizo-Pedroso \& Del-Claro (2007) suggest advantages and disadvantages for this kind of relationship, and Zeh \& Zeh (1992c) considered predation behavior as the origin of phoresy. There are two characteristic types of phoresy: Active phoresy, when the phoront holds or clings to any structure of the host's body and passive phoresy, when the phoront places itself beneath or within any structure or cavity of the host (Vachon 1940; Athias-Binche 1994).

We document the presence of the pseudoscorpion $L$. grossus, coexisting with the passalid $O$. striatopunctatus through an observational study in captivity and to discuss the phoretic relationship between the two species.

\section{MATERIALS AND METHODS}

In September 2000 and in October 2001, 20 adults of $O$. striatopunctatus were collected in a remnant of cloud forest, located $3 \mathrm{~km}$ southwest of the city of Xalapa, Veracruz, Mexico (19³0'38', N, 96 57' 03' ' W) at $1300 \mathrm{~m}$ asl. The climate in the area is humid temperate (Peel et al. 2007), the annual average temperature is $18{ }^{\circ} \mathrm{C}$, with an annual rainfall of $1490.5 \mathrm{~mm}$ a factor that helps maintain high humidity.

In order to obtain offspring of passalids, 16 breeding terrariums were set, (six in the first year and ten in the second year), placing a couple (male and female) of $O$. striatopunctatus in a decaying log segment about $30 \mathrm{~cm}$ long and $15-20 \mathrm{~cm}$ in diameter. The logs were previously segmented in longitudinal sections (2.5-3 cm thick) with the aid of an electric saw, and tied with rubber bands to hold them together; this design facilitates monthly observations inside the galleries without disturbing the passa- 
Table 1. Species of passalids and pseudoscorpions exclusive of the American Continent, recorded together, coexisting in decaying logs. $(*)$ It is the only passalid with different habitat, the dumps of ants of the genus Atta.

\begin{tabular}{|c|c|c|}
\hline Passalidae species & Pseudoscorpionida species & Bibliographical source \\
\hline Passalus abortivus Percheron, 1835 & $\begin{array}{l}\text { Tridenchthonius mexicanus Chamberlin \& } \\
\text { Chamberlin, 1945, Lustrochernes intermedius } \\
\text { (Balzan), Lustrochernes aff. reimoseri }\end{array}$ & Aguiar \& Bührnheim, 1992, 1998 \\
\hline Passalus aff. coarctatus Percheron, 1835 & $\begin{array}{l}\text { T. mexicanus, L. aff. reimoseri, Americhernes } \\
\text { aff. incertus }\end{array}$ & Aguiar \& Bührnheim, 1992, 1998 \\
\hline Passalus convexus Dalman,1817 & T. mexicanus, L. aff. reimoseri, A. aff. incertus & Aguiar \& Bührnheim, 1992, 1998 \\
\hline Passalus epiphanoides (Kuwert,1891) & L. aff. reimoseri, T. mexicanus & Aguiar \& Bührnheim, 2011 \\
\hline Passalus glaberrimus Eschschholtz, 1829 & L. aff. reimoseri, A. aff. incertus, T. mexicanus & Aguiar \& Bührnheim, 1998, 2011 \\
\hline Passalus interstitialis Eschscholtz, 1829 & $\begin{array}{l}\text { T. mexicanus, L. intermedius, L. aff. reimoseri, } \\
\text { V. gracilimanus, Lustrochernes similis } \\
\text { (Balzan), Phymatochernes crassimanus } \\
\text { Mahnert 1979, Lechytia chthoniiformis } \\
\text { (Balzan), Dolichowithius.(D.) emigrans } \\
\text { (Balzan), Lustrochernes sp. }\end{array}$ & $\begin{array}{l}\text { Aguiar \& Bührnheim, 1992, 1998, 2011; } \\
\text { Villegas-Guzmán \& Reyes-Castillo, 2005, } \\
2012\end{array}$ \\
\hline Passalus latifrons Percheron, 1841 & T. mexicanus, L. aff. reimoseri, L. intermedius & Aguiar \& Bührnheim, 1992, 1998, 2011 \\
\hline Passalus aff. nasutus Percheron, 1835 & T. mexicanus, L. aff. reimoseri, A. aff. incertus & Aguiar \& Bührnheim, 1998, 2011 \\
\hline $\begin{array}{l}\text { Passalus (P.) punctiger Lepeletier \& Serville, } \\
1825\end{array}$ & $\begin{array}{l}\text { T. mexicanus, Incachernes mexicanus Beier, } \\
\text { 1933, Lustrochernes argentinus (Thorell), } \\
\text { Lustrochernes crassimanus Beier, 1933, L. } \\
\text { intermedius, Juxtachelifer fructuosus Hoff } \\
\text { 1956, Lustrochernes sp. }\end{array}$ & $\begin{array}{l}\text { Beier 1948; Reyes-Castillo \& Hendrichs, } \\
\text { 1975; Aguiar \& Bührnheim, 1998, 2011; } \\
\text { Villegas-Guzmán \& Reyes-Castillo, 2005, } \\
2012\end{array}$ \\
\hline Passalus (M.) spinifer Percheron, 1841 & T. mexicanus, L.aff. reimoseri & Aguiar \& Bührnheim, 1998 \\
\hline Passalus unicornis Lepeletier et Serville, 1825 & $\begin{array}{l}\text { T. mexicanus, L. aff. reimoseri, A. aff. incertus, } \\
\text { V. gracilimanus }\end{array}$ & Aguiar \& Bührnheim, 1992, 1998 \\
\hline $\begin{array}{l}\text { Passalus aff. unicornis Lepeletier \& Serville, } \\
1825\end{array}$ & L. intermedius, T. mexicanus & Aguiar \& Bührnheim, 2011 \\
\hline Passalus variiphyllus Kuwert, 1891 & $\begin{array}{l}\text { T. mexicanus, L. aff. reimoseri, A. aff. incertus, } \\
\text { P. homodentatus }\end{array}$ & Aguiar \& Bührnheim, 1992, 1998, 2011 \\
\hline Spasalus crenatus (MacLeay, 1819) & T. mexicanus & Aguiar \& Bührnheim, 2011 \\
\hline Spasalus robustus (Percheron, 1835) & L. intermedius & Aguiar \& Bührnheim, 1998 \\
\hline Paxillus leachi MacLeay, 1819 & L. intermedius, C. scorpioides, T. mexicanus & Aguiar \& Bührnheim, 1998, 2011 \\
\hline
\end{tabular}


Table 1. Continue.

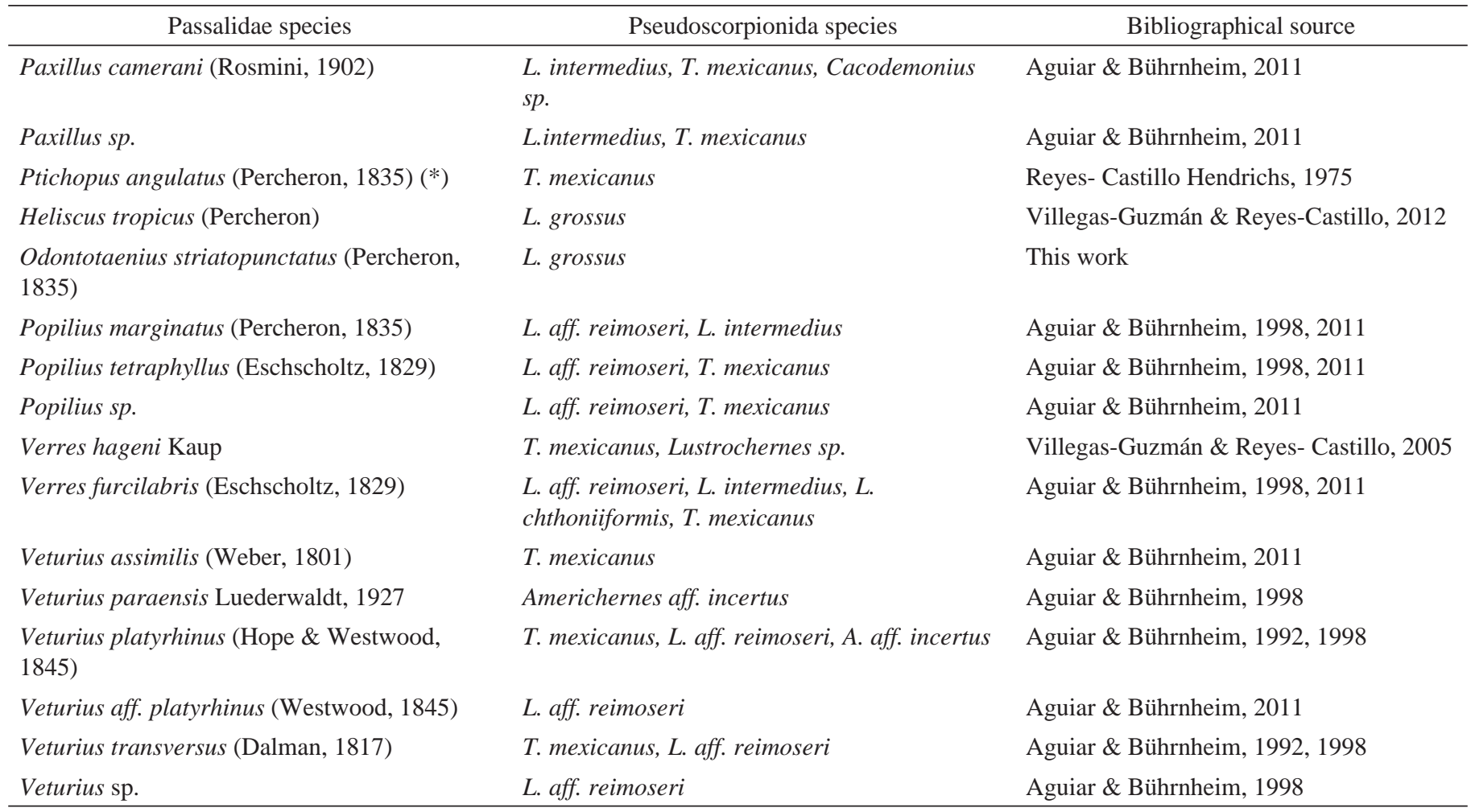

lids (Hernández-Martínez \& Castillo 2003). Throughout the handling process the logs showed no organisms, and were kept individually in plastic containers $(37 \mathrm{~cm} \times 28$ $\mathrm{cm} \times 20 \mathrm{~cm}$ ) at $27^{\circ} \mathrm{C}$ and $80 \%$ relative humidity, with a 14-hour light period.

Two reproduction periods of nine months each were conducted: the first one began on January $20^{\text {th }}$ and ended on October $11^{\text {th }} 2001$, and the second was launched on October $17^{\text {th }} 2001$ and ended on July $9^{\text {th }} 2002$. In the second period ten couples were made with some of the young adult passalids obtained from the first period and adults from the second collection (Table 2).

Monthly observations of passalid family groups were conducted to record their stage of development, which consisted of removing the rubber bands, separating the "log segments" carefully and examining the contents of the galleries; during observations the presence of pseudoscorpions in the nests was registered with ad libitum sampling (Martin \& Bateson 1986). To avoid disrupting the passalids and their reproduction, no direct observations were made under their elytra.

For identification, three female and three male pseudoscorpions were prepared using the Hoff (1949) technique with modifications by Wirth \& Marston (1968).
The specimens are deposited in the National Arachnids Collection of the Institute of Biology of the National Autonomous University of Mexico. Voucher specimens of $O$. striatopuncatatus are deposited in the collection of insects (IEXA) of the Institute of Ecology in Xalapa, Veracruz, Mexico.

\section{RESULTS}

Pseudoscorpions were found in 11 of 16 passalids nests, in the two breeding periods. In the first period they were present in half of the nests (three out of six), and in the second, pseudoscorpions occurred in eight of ten nests (Table 2). Fifty one observations were made in the 11 nests where pseudoscorpions were present. In 17 observations (33\%) from one to many were seen. These pseudoscorpions were $L$. grossus, being the first pseudoscorpion recorded on $O$. striatopunctatus.

When starting each of the two breeding periods, no pseudoscorpions were found on passalids or on the breeding device. In all cases, individuals of $L$. grossus became evident within the nests when adults of $O$. striatopunctatus were successfully established inside the log. Establish- 
Table 2. Presence of Lustrochernes grossus in nests of Odontotaenius striatopunctatus.

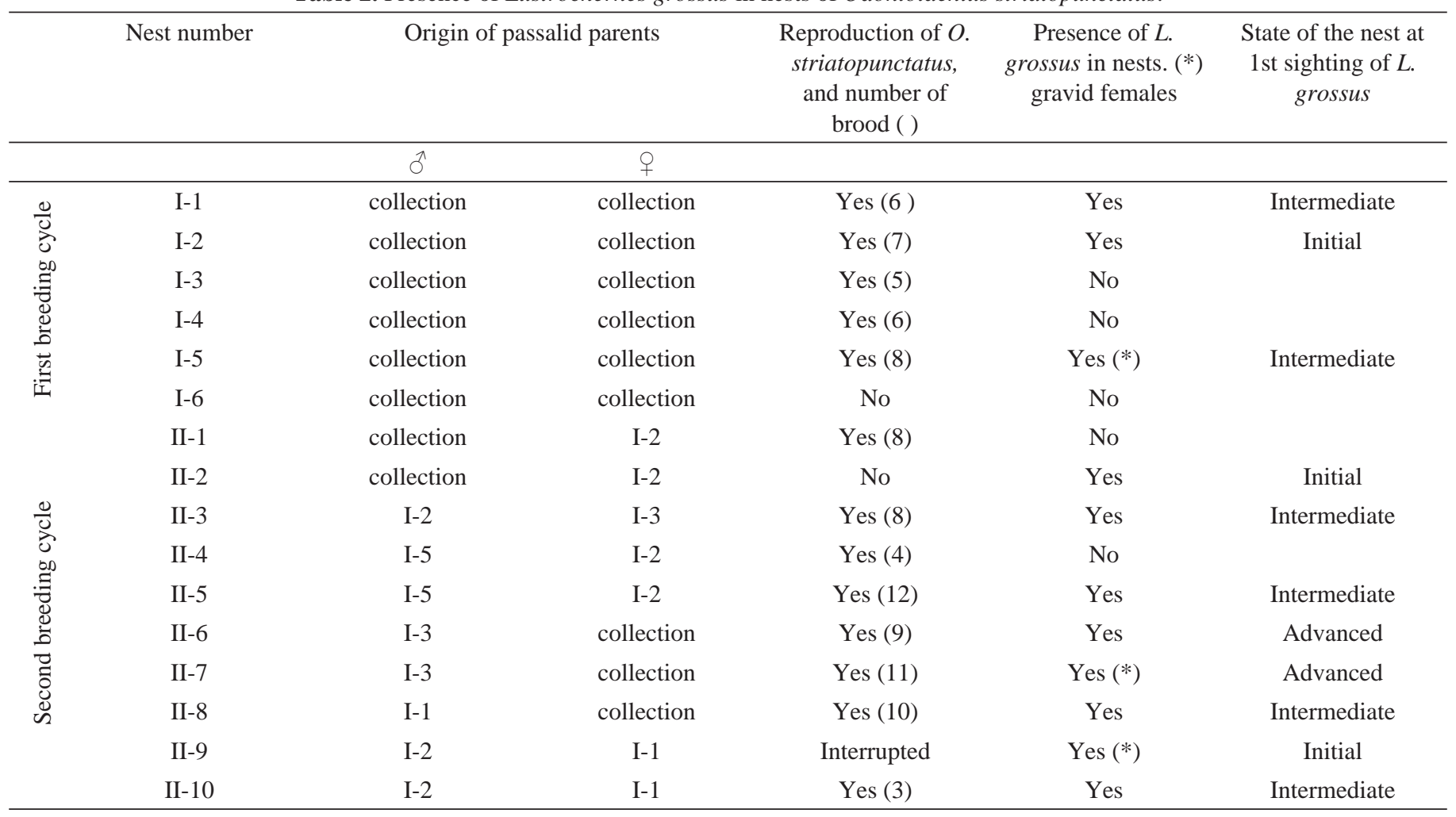

ment was evident through the active building of galleries, the preparing of food for the offspring, the increased amount of saw dust, debris, space inside the trunk, and of course, the presence of offspring.

Due to the fact that no direct observations were made under the passalid's elytra to avoid disturbing them, and initially the logs didn't have these organisms, we believe that pseudoscorpions were under the elytra of adult passalids from the moment they were collected. We substantiated this assumption during the second period of passalid collection when splitting a log with an axe, we accidentally hurt two adult males and observed three pseudoscorpions of the same species under their elytra, one male and two female adults (Fig. 1). As is common with passalids, mites were also found on them (Hunter 1993; VillegasGuzmán et al. 2012.).

During the two nine month passalid nests observation periods, breeding was successful in 13 of the 16 nests. The presence of pseudoscorpions was evident in nine of them, which shows that the presence of $L$. grossus was no impediment to the successful reproduction of the host (Fischer exact test: $P=0.71, n=16$ ) (Table 2). Similarly, the number of passalids offspring was not affected by the presence of $L$. grossus individuals (Mann Whitney $U=$ 11.50, $P=0.2553$ ) (Table 2).

On three occasions, at the beginning of spring, females of $L$. grossus carrying their egg sac adhered to the ventral abdomen were observed: in April 2001 (nest I-5) and in March and April 2002 (nests II-7 and II-9), females were observed in the passalid galleries, $35 \mathrm{~mm}$ from the adult passalids. One of the egg sacs had 19 eggs (nest II-7). No silk chambers remnants were observed.

In the second breeding period, pseudoscorpions were found in eight of the ten nests and in four of these, the passalids came from the first breeding period, where $L$. grossus was present, while in the other four cases they could come from passalids collected in the field and/or from the first breeding period (Table 2). In all cases, we believe that pseudoscorpions came under the elytra of their guests, the founding passalids.

On several occasions throughout the observations of nests, we could observe the presence of pseudoscorpions in the galleries and their proximity to the passalids (15-45 $\mathrm{mm}$ ) some also clinging onto adults and larvae, and even under the misshapen elytra of a juvenile passalid (Figs. 2 and 3). 


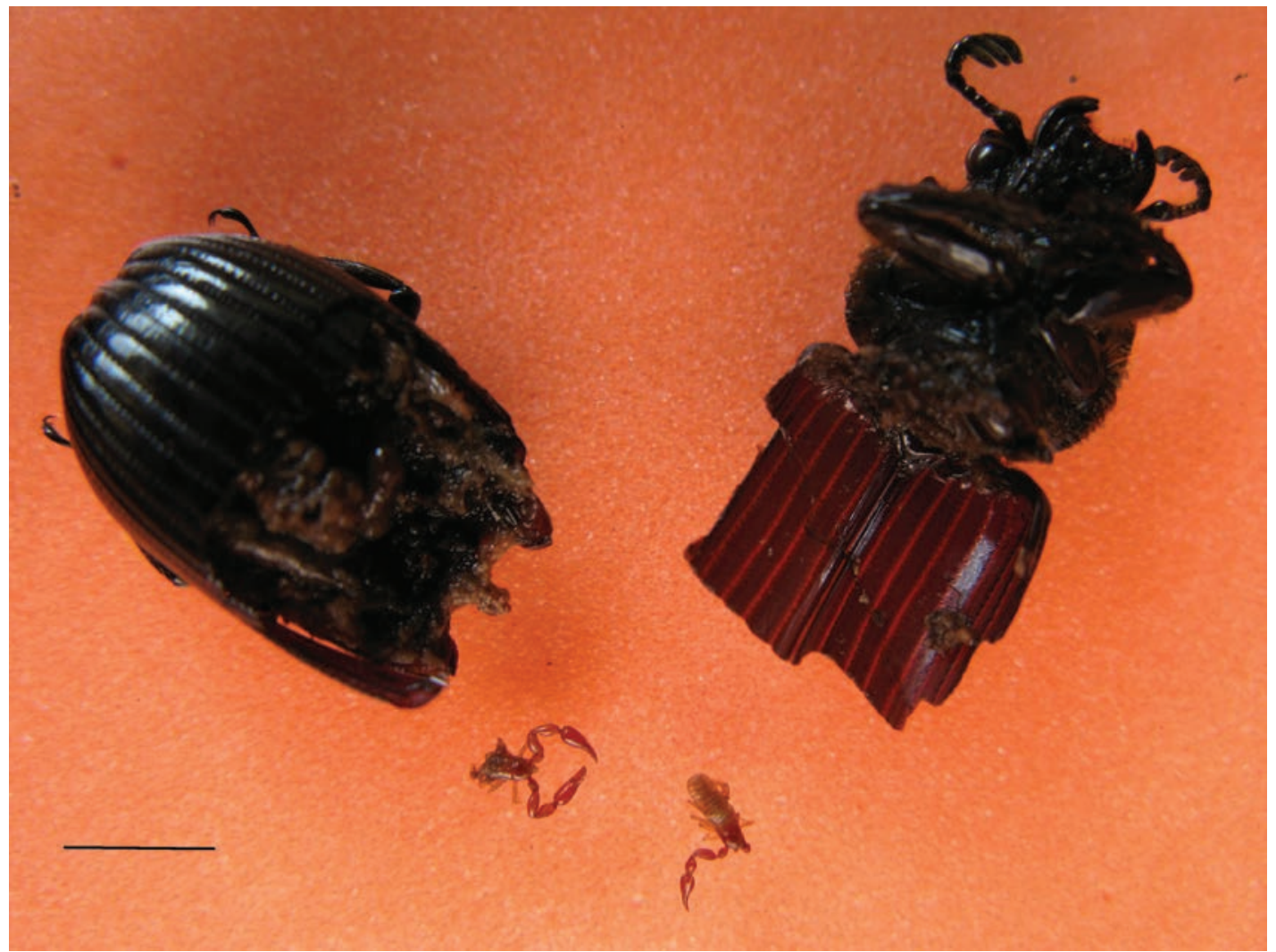

Figure 1. Adult male of Odontotaenius striatopunctatus and two specimens of Lustrochernes grossus damaged during collection. Scale bar $=3 \mathrm{~mm}$.

\section{DISCUSSION}

The association of the pseudoscorpion $L$. grossus with its host $O$. striatopunctatus was recorded for the first time. Cited cases of pseudoscorpions and passalids in the Americas thus increase to 36 (Table 1). Individuals of $L$. grossus travel under the elytra of passalids, just as other pseudoscorpions of the same genus do, with their hosts (Aguiar \& Bührnheim 1992). Apparently, pseudoscorpions get off the passalids to get into the decaying logs, where beetles begin building their nest. In the nests there is much of debris produced by passalids, which favors the presence of mites and other micro-arthropods that can serve as food for the psudoscorpions (Weygoldt 1969).

Odontotaenius striatopunctatus successfully bred within the nests unaffected by L. grossus. The presence of pseudoscorpions increased from the initial three to the eight nests set for the second breeding period, which meant their establishment in this type of habitat and their passing from the parent passalids to their offspring, the presence of $L$. grossus does not seem to affect them (Table 2).
The presence of $L$. grossus females with brood sac was evident in three passalids nests with different stages of family development: a) in the presence of eggs, b) with larvae of different instars c) with young adults. It is worth mentioning that passalids are subsocial Coleoptera (Wilson 1971), they may show overlapping generations in their nests, a situation that allows extending the life of the colony for a longer time inside the dead tree. This may allow pseudoscorpion nymphs that have not yet matured to do so, and to be able to disperse among a new generation of passalids.

Based on observations made by Aguiar \& Bührnheim (1992) in Amazons on developmental stages of pseudoscorpion species traveling on passalids, a low frequency of phoronts in immature stages was found (tritonymphs), as well as gravid females. Most phoretic pseudoscorpions are adults of both sexes; there is in particular a higher proportion of males for three species of pseudoscorpions: Tridenchtonius mexicanus, Chamberlin \& Chamberlin 1945, Lustrochernes intermedius (Balzan 1891) and L. aff. reimoseri. Beier 1932. The same is reported 


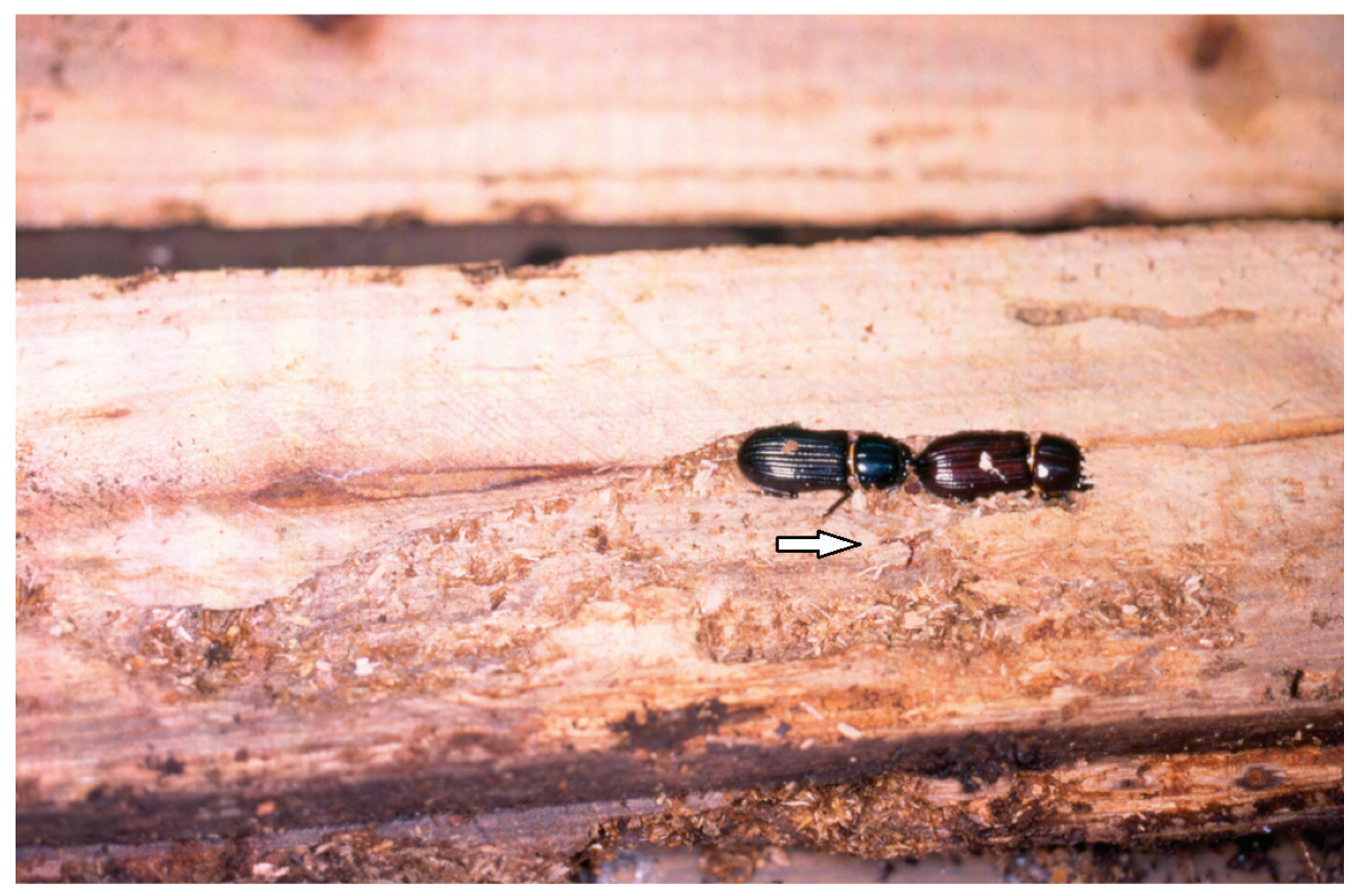

Figure 2. Adult couple of Odontotaenius striatopunctatus in their nest next to a specimen of Lustrochernes grossus. Scale bar $=1.5 \mathrm{~cm}$.

by Tizo-Pedroso \& Del-Claro (2007) studying Paratemnoides nidificator (Balzan 1888) where they also found adult pseudoscorpions of both sexes. In this study, we found one male and two female adults that confirm the suggestion by Vachon (1940), regarding pseudoscorpions traveling under the elytra of Coleoptera, indicated that individuals of both sexes have been found.

As for phoronts preference for host age, Poinar et al. (1998) and Eickwort (1990) indicate a preference for adult hosts, since they have greater mobility and are potential builders of new nests. The fact that $L$ grossus remain for some time in the nests with the passalids means that it is here where they make contact with their lignicolous hosts, sharing the microhabitats, which enables them to determine the right time to ride on them before dispersal, as suggested by Beier (1948) and Muchmore (1971a, b).

It was common to see L. grossus cohabiting in the nests and even on both, adult individuals and larvae of $O$. striatopunctatus (Fig. 2). Phoronts may well get close to their hosts waiting for the moment of dispersion. Something similar happens between A. longimanus and C. scorpioides, since three to five generations of pseudoscorpions remain within the dead tree, until a cerambycid larva completes its development and they can then disperse (Zeh \&
Zeh 1997). In the case of passalids, young adults remain inside the log for several weeks, until they reach maturity. Another example occurs between the pseudoscorpion Dinocheirus arizonensis (Banks 1901) and the fly Odontoloxozus longicornis Coquillett, which inhabits decaying saguaro cactus (Zeh \& Zeh 1992b).

According to Athias-Binche (1994) and Vachon's (1940) classification, L. grossus performs passive phoresy on O. striatopunctatus, as it travels under its elytra. For Beier (1948) in addition to phoresy, this relationship is considered phagophilic as Vachon (1940) emphasizes that not only do they seek transportation but they also feed on mites found on the host, although in this study there is not direct evidence of feeding on the host.

Weygoldt (1969) has observed this behavior pattern in pseudoscorpions of the Chernetidae, where they sanitize their carriers by removing phoretic mites from their body surface. In this study, mites were found on O. striatopunctatus; thus, it is possible that pseudoscorpions had fed on some. Villegas-Guzmán \& Reyes-Castillo (2005) observed in Chiapas, an individual of Lustrochernes feeding on a mite beneath the elytra of a passalid.

The relationship between $L$. grossus and $O$. striatopunctatus might be phoretic-phagophilic providing mu- 


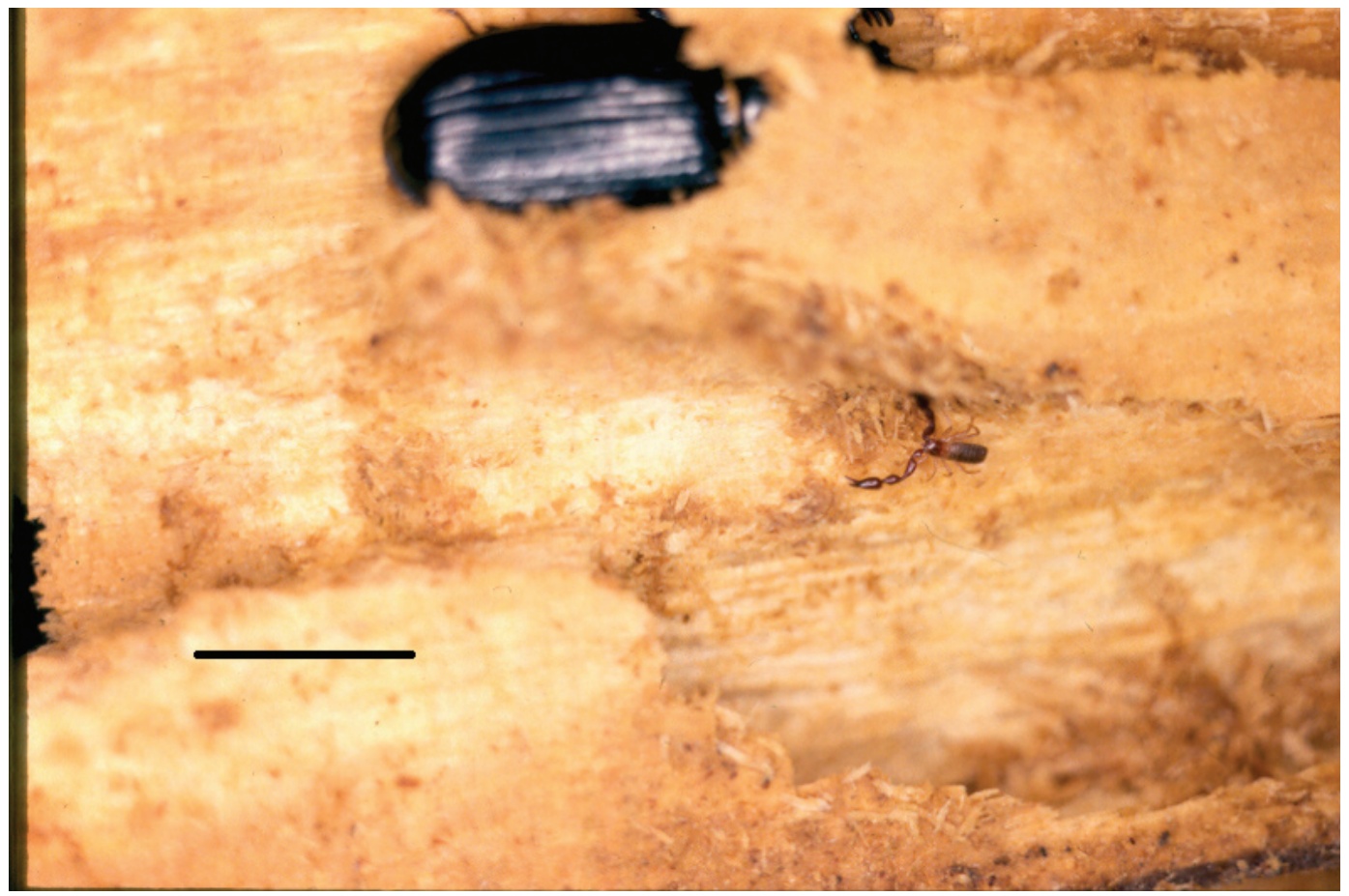

Figure 3. Lustrochernes grossus in the nest under construction, together with Odontotaenius striatopunctatus, close up. Scale bar $=7.5$ mm.

tual potential benefit between the two organisms; $O$. striatopunctatus, having mites and parasite control within their galleries, and $L$. grossus having a proper place to live, with the possibility of finding food facilitating its reproduction and ensuring transportation for later dispersal.

The relationship between pseudoscorpions and passalids is facultative, since both organisms can live independently from each other in decaying logs; therefore, it is not surprising that $L$. grossus chooses other lignicolous organisms as possible dispersing agents, as in the case of cerambycids (Mahnert \& Adis 1985).

Lustrochernes grossus is a very plastic species that has been reported on various arthropods (Muchmore 1971a, 1991; Hoff \& Jennings 1974) and even on small mammals (Villegas-Guzmán \& Pérez 2005b). Nonetheless, the lignicolous or corticicolous microhabitat plays a very important role in order for the encounter between phoront and host to take place.

The records between different species of the genus Lustrochernes and passalids (Table 1) show that the relationship between the two organisms is frequent and apparently nonspecific, resulting in the sinhospitality phenomenon, in which a kind of phoront uses more than one host species. Extremely specific phorethic associa- tions might be counterproductive; undoubtedly they involve high risks for the specialization of the phoront with its hosts. From tertiary amber records, we know that, 40 million years ago, phoresy was already established (Ross 1997; Poinar et al. 1998), and cases of specificity are scarce; in extant cases many lignicolous host can be use by the pseudoscorpions.

As reported by Reyes-Castillo \& Hendrichs (1975), passalids that have been found with pseudoscorpions are species of wide geographical distribution and good flying habits, at least among neotropical species. Such characteristics are present in O. striatopunctatus, which favors the dispersion of pseudoscorpions, making phoresy an effective method for their distribution, Lustrochernes is widely distributed in the Americas and its family Chernetidae is one of the most diverse of the Pseudoscorpionida in which it is common to find cases of phoresy (Beier 1948; Muchmore 1971a, 1971b).

ACKNOWLEDGEMENTS. Our thanks to Gerardo Hernández Martínez for his great concern and initiative in collecting passalids, to Oscar Francke and Pedro Reyes-Castillo for reading and making suggestions regarding the manuscript, to Rogelio Macias for the constructive discussion on the topic and two reviewers for their significant comments. 


\section{LITERATURE CITED}

Aguiar, N. O. \& Bührnheim, P. F. 1992. Pseudoscorpiones (Arachnida) em associação forética com Passalidae (Insecta, Coleoptera) no Amazonas, Brasil. Amazonia, 12: 187-205.

Aguiar, N. O. \& Bührnheim P. F. 1998. Phoretic pseudoscorpions associated with flying insects in Brazilian Amazonia. Journal of Arachnology, 26: 452-459.

Aguiar, N. O. \& Bührnheim. P. F. 2011. Pseudoscorpionida (Arachnida) em galerias de colônias de Passalidae (Coleoptera, Insecta) em troncos caídos em floresta de terra firme da Amazônia, Brasil. Acta Amazonica, 41: 205-212.

Athias-Binche, F. 1994. La phorésie chez les acariens. Aspects adaptatifs et Evolutifs. Castillet, Perpignan, Paris. 178 pp.

Beier, M. 1948. Phoresie und Phagophilie bei Pseudoscorpionen. Österreichische Zoologische Zeitschrift, 1: 441-497.

Castillo, M. L. \& Reyes-Castillo, P. 2003. Los Passalidae: coleópteros tropicales degradadores de troncos de árboles muertos, Pp. 237262. In: J. Álvarez-Sánchez \& E. Naranjo García (Eds.). Ecología del Suelo en la Selva Tropical Húmeda de México. Instituto de Ecología, A.C., Instituto de Biología y Facultad de Ciencias, UNAM. Xalapa, México.

Eickwort, G. C. 1990. Associations of mites with social insects. Annual Review of Entomology, 35: 469-488.

Francke, O. F. \& Villegas-Guzmán, G. A. 2007. Symbiotic relationships between pseudoscorpions (Arachnida) and packrats (Rodentia). Journal of Arachnology, 34: 289-298.

Hernández-Martínez, G. \& Castillo, M. L. 2003. Modified logs as a means for rearing and observing sapwood/heartwood dwelling passalids (Coleoptera: Passalidae) in the laboratory. The Coleopterists Bulletin, 57: 243-244.

Hoff, C. C. 1947. Two new pseudoscorpions of the subfamily Lamprochernetinae from Venezuela. Zoologica, 32: 61-64

Hoff, C. C. 1949. The pseudoscorpions of Illinois. IIlinois Natural History Survey Buletin, 24: 409-498.

Hoff, C. C. \& Jennings, D. T. 1974. Pseudoescorpions on a spider. Entomological News, 85: 21-22.

Hunter, P. E. 1993. Mites associated with New World passalid beetles (Coleoptera: Passalidae). Acta Zoológica Mexicana (n.s.), 58: 137.

Mahnert, V. \& Adis, J. 1985. On the occurrence and habitat of Pseudoscorpiones (Arachnida) from Amazonian forest of Brazil. Studies on Neotropical Fauna and Environment, 20: 211-215.

Martin, P. \& Bateson, P. 1986. Measuring Behaviour. Cambridge University Press. 186 pp.

Muchmore, W. R. 1971a. Phoresy by North and Central American pseudoscorpions. Proceedings of the Rochester Academy of Science, 12 : 77-97.

Muchmore, W. R. 1971b. On phoresy in pseudoscorpions. Bulletin of the British Arachnological Society, 2: 38.

Muchmore, W. R. 1991. The identity of Chelifer communis var. pensylvanicus and description of a new species of Lustrochernes (Pseudoscorpionida: Chernetidae). Entomological News, 102: 7989.

Ohaus, F. 1909. Bericht über eine entomologische Studienreise in Südamerika. Stettiner Entomologische Zeitung, 70: 3-139.

Peel, M. C., Finlayson, B. L. \& McMahon, T. A. 2007. Updated world map of Köppen-Geiger climate classification. Hydrology Earth System Science Discussion, 4: 439-473.

Poinar, JR. G. O., Ćurčić, B. P. M. \& Cokendolpher, J. C. 1998. Arthropod phoresy involving pseudoscorpions in the past and present. Acta Arachnologica, 47: 79-96.

Reyes-Castillo, P. 1970. Coleoptera, Passalidae: morfología y división en grandes grupos géneros americanos. Folia Entomológica Mexicana, 20-22: 1-240.

Reyes-Castillo, P. \& Halffter, G. 1984. La estructura social de los Passalidae (Coleoptera: Lamellicornia). Folia Entomológica Mexicana, 61: 49-72.

Reyes-Castillo, P. \& Hendrichs, J. 1975. Pseudoescorpiones asociados con pasálidos. Acta Politécnica Mexicana, 16: 129-133.

Ross, A. J. 1997. Insects in amber. Geology Today, 13: 24-28.

Schuster, J. C. \& Schuster, L. B. 1997. The evolution of social behavior in Passalidae (Coleoptera), Pp. 260-269. In: J.C. Choe \& B.J. Crespi (Eds.). The Evolution of Social Behavior in Insects and Arachnids, Cambridge University Press, UK.

Szymkowiak, P., Górski, G. \& Bajerlein, D. 2007. Passive dispersal in arachnids. Biological Letter, 44: 75-101.

Tizo-Pedroso, E. \& Del-Claro, K. 2007. Cooperation in the Neotropical pseudoscorpion, Paratemnoides nidificator (Balzan, 1888): feeding and dispersal behavior. Insectes Sociaux, 54: 124-131.

Vachon, M. 1940. Remarques sur la phorésie des pseudoscorpions. Annales de la Societé Entomologique de France, 109: 1-18.

Valenzuela G., J. \& Castillo, M. L. 1983. Contribution à l'étude du comportement chez les Passalidae. Bulletin de la Societé Entomologique de France, 88: 607-618.

Villegas-Guzmán, G. A. \& Pérez, T. M. 2005a. Hallazgo de pseudoescorpiones (Arachnida: Pseudoscorpionida) foréticos de Felis catus Linnaeus, 1758 en la ciudad de México. Folia Entomológica Mexicana, 44: 85-87.

Villegas-Guzmán, G. \& Pérez, T. M. 2005b. Pseudoescorpiones (Arachnida: Pseudoscorpionida) asociados a nidos de ratas del género Neotoma (Mammalia: Rodentia) del Altiplano Mexicano. Acta Zoológica Mexicana, (n.s.), 21: 63-77.

Villegas-Guzmán, G. A. \& Reyes-Castillo, P. 2005. Pseudoescorpiones (Arachnida: Pseudoscorpionida) foréticos de pasálidos (Insecta: Coleoptera) de Frontera Corozal, Chiapas. Pp. 20-22. In: A. Morales-Moreno, A. Mendoza-Estrada, M. P. Ibarra-González y S. Stanford-Camargo, (Eds.). Entomologica. Vol. 4. Sociedad Mexicana de Entomología, A.C. Texcoco.

Villegas-Guzmán, G. A. \& Reyes-Castillo, P. 2012. Pseudoescorpiones (Arachnida: Pseudoscorpionida) foréticos de pasálidos (Insecta: Coleoptera) del Sureste de México. Pp. 89-93. In: A. Equihua-Martínez, E. G. Estrada-Venegas, J. A. Acuña-Soto, M. P. Chaires-Grijalba y G. Durán-Ramírez (Eds.). Entomologíca. Vol. 11. Sociedad Mexicana de Entomología A.C. Texcoco.

Villegas-Guzmán, G. A., Francke, O. F., Pérez, T. M. \& ReyesCastillo, P. 2012. Coadaptación entre los ácaros (Arachnida: Klinckowstroemiidae) y coleópteros Passalidae (Insecta: Coleoptera). Revista de Biología Tropical, 60: 599-609.

Weygoldt, P. 1969. The Biology of Pseudoscorpions. Harvard University Press, Cambridge, Massachusetts, USA. 159 pp.

Wilson, E. O. 1971. The Insect Societies. Harvard University Press, Cambridge, Massachusetts, USA. 562 pp.

Wirth, W. W. \& Marston, N. 1968. A method for mounting small 
insects on microscope slides in Canada balsam. Annals of the Entomological Society of America, 61:783-784.

Zeh, D. W. \& Zeh, J. A. 1992a. On the function of harlequin beetle-riding in the pseudoscorpion, Cordylochernes scorpioides (Pseudoscorpionida: Chernetidae). Journal of Arachnology, 20: 47-51.

Zeh, D. W. \& Zeh, J. A. 1992b. Dispersal-generated sexual selection in a beetle-riding pseudoscorpion. Behavioral Ecology and Sociobiology, 30: 135-142.

Zeh, D. W. \& Zeh, J. A. 1992c. Failed predation or transportation? Causes and consequences of phoretic behavior in the pseudoscor- pion Dinocheirus arizonensis (Pseudoscorpionida: Chernetidae). Journal of Insect Behavior, 5(1): 37-49.

Zeh, D. W. \& Zeh, J. A. 1997. Sex via substrate: mating systems and sexual selection in pseudoscorpions, Pp. 329-339. In: J. C. Choe \& B. J. Crespi (Eds.). The Evolution of Mating Systems in Insects and Arachnids, Cambridge University Press, UK.

Zeh, D. W., Zeh, J. A. \& Tavakilian, G. 1992. Sexual selection and sexual dimorphism in the harlequin beetle Acrocinus longimanus. Biotropica, 24: 86-96.

Zeh, J. A. \& Zeh, D. W. 1994. Tropical liaisons on a beetle’s back. Natural History, 103: 36-43. 